\title{
VICARIUS, CANONICUS ET EPISCOPUS: THREE LATE MEDIEVAL GRAVE SLABS FROM TARTU AND TALLINN
}

In June 2008, an incised Late Medieval grave slab came to light during the archaeological excavations of Tartu Cathedral. ${ }^{2}$ The rectangular slab is made of limestone, decorated with the figure of a cleric and with a Latin inscription in Gothic minuscule (Fig. 1). The dimensions of the slab are $207 \times 136 \mathrm{~cm}$, but almost a quarter of it - a large part of the upper left corner - has been lost. Since October 2013, the object, which belongs to Tartu City Museum, has been exhibited under the floor in the foyer of the University of Tartu's History Museum, above a medieval burial chamber (there is no connection between the two). ${ }^{3}$

There are two main reasons why this grave slab warrants attention. Firstly, there are very few surviving medieval grave slabs or their fragments in present-day Estonia that are decorated with human figures. ${ }^{4}$ Secondly, the inscription allows us to add a new name to the list of cler-

DOI: http://dx.doi.org/10.12697/BJAH.2014.7.02

1 The article was supported by institutional research funding IUT18-8 of the Estonian Ministry of Education and Research. I am grateful to Tiina Kala, Ivar Leimus and Ando Pajus for their comments.

2 For the precise location and context, see Martin Malve, Heiki Valk, "Archaeological Excavations in Tartu Cathedral”, Arheoloogilised välitööd Eestis 2008 / Archaeological Fieldwork in Estonia 2008 (Tallinn, 2009), 145-146, fig. 1, 3-4.

3 Tartu Postimees, 4 October 2013: http://www.tartupostimees.ee/2127674/toomel-pandi-vaatamiseks-valja-haruldane-hauakivi, and 7 October 2013: http://www.tartupostimees.ee/2328646/ hauaplaadi-tostmine-kujunes-raskeks-pahkliks.

4 Most of them belong to ecclesiastics, see Mari Loit, "Keskaegsest surmakultuurist ja hauatähistest reformatsioonieelse Tallinna kirikutes ja kloostrites”, Vana Tallinn, XVII (XXI) (Tallinn, 2006), 74-75, 113-115. For the pre-war situation related to figural tombstones from medieval Livonia, see Heinz Loeffler, Die Grabsteine, Grabmäler und Epitaphien in den Kirchen Alt-Livlands vom 13.-18. Jahrhundert (Riga: Löffler, 1929), 18-19, 22-27. 
Fig. 1. Grave slab of Stephanus de Velde, 1428 or 1438. Excavated from the Tartu Cathedral, displayed at the University of Tartu History Museum. Photo by Andres Tennus. 
ics known from medieval Tartu. This archaeological find inspired me to explore all the extant figural grave slabs belonging to the Catholic clergy up to the middle of the $16^{\text {th }}$ century. And in this article, I would like to discuss three of them, which represent ecclesiastics of different ranks - a vicar, a canon and a bishop. None of these slabs has been thoroughly studied earlier. By examining their visual appearance and inscriptions, some of the general trends in the production and decoration of local tombstones can be outlined and a contribution made to the discussion of the role of such monuments in the Late Medieval culture of commemoration.

\section{STEPHANUS DE VELDE}

The incised grave slab (Fig. 1) depicts a man, standing in front view and holding a book in his left hand (the right arm is missing). The deceased is wearing liturgical garments - a chasuble, decorated with a Y-shaped cross, and under it, an alb. He is also wearing liturgical headgear, most probably a biretta surmounted by a tuft. Above the figure, there is a Gothic canopy, decorated with crabs and supported by slender pillars. The canopy, as well as a small window in the upper right corner, probably alludes to a sacral space - the church. At the figure's feet, there is a coat of arms; however, instead of a heraldic emblem, the entire shield is covered in a pattern of lozenges. The shape of the shield is characteristic of the $15^{\text {th }}$ century and the early $16^{\text {th }}$ century. ${ }^{5}$

The figure, as well as the architectural frame, is executed in a rather schematic manner. The face is stereotypic, with no traces of individuality. The artist's main purpose has been to express the status of the deceased so that the viewers would clearly recognize a learned man of ecclesiastical rank.

Most of the Late Medieval grave slabs in Estonia (and elsewhere in northern Europe) have circular or quatrefoil decorations in the corners, usually depicting the symbols of the four Evangelists, or, less frequently, roses or crosses. However, on the slab under discussion, there are no corner decorations. Instead, it is framed with an inscription in two rows. More precisely, the borderlines of the two rows have been marked on

5 See Est-und Livländische Brieflade, Teil 4: Siegel und Münzen der weltlichen und geistlichen Gebietiger über Liv-, Est- und Curland bis zum Jahre 1561 (hereafter Brieflade 4: Siegel und Münzen), hrsg. v. Robert von Toll, Johannes Sachssendahl (Reval: Kluge \& Ströhm, 1887), passim. 
the slab, but the text exists only in the outer row and on two sides of the inner row (above and right). The text has survived best in the two rows on the right side, whereas, on the other three sides, some of the letters have been damaged. Because of the broken section, the beginning and end of the outer row and the beginning of the inner row are missing.

Traditionally, the inscriptions on grave slabs begin with the date of death. Here, most of the symbols forming the year have been lost; the first letter that can clearly be identified is the Roman numeral X, followed by the word octo, i.e. in the eighth year. By closely examining the broken surface, it can be concluded that the symbol before the $\mathrm{X}$ has been the same shape, i.e. another ten. Since the general stylistic features of the grave slab point to the $15^{\text {th }}$ century, the following years can be considered: 1428, 1438, 1478 and 1488. Grave slabs from German cities with similar elements (based on the shape of the letters, the form of the eyes, folding, canopy, etc.) originate mainly from the first half of the $15^{\text {th }}$ century. ${ }^{6}$ A grave slab in St Nicholas's Church in Stralsund, belonging to the priest Borchardus Plocze (Plotze), who died in 1437, can particularly well be compared to that of Stephanus (Fig. 2). Although the shape of the coat of arms at Stephanus's feet is more widely spread in the second half of the $15^{\text {th }}$ century, it also occurs in the first half of the century. ${ }^{7}$ It should also be pointed out that in the second half of the $15^{\text {th }}$ century, grave slabs were usually executed in low relief, whereas incised slabs were characteristic of the earlier periods. Therefore, it can be suggested that Stephanus de Velde died either in 1428 or 1438.

As was typical of Medieval Latin inscriptions, several words have been abbreviated. The outer row of the inscription reads as follows: $[---]<x>x$ octo $u[---]$ tis a na/talicio d[omi]ni felice notis vir sapiens d[omi]n[u] s stephan[us] de velde votus / atq[ue] vicari[us] hic defu[n]ct[us] hic est [---] natus / cu[m] steph[an] [---] fine(?) [---]. Translation: "In the eighth year of (1420 or 1430) after the birth of the Lord, a wise man of happy renown, Master Stephanus de Velde, the sworn one and vicar, has died here. Here is [---] with Stephanus [---]."

6 Martin Lehmann, Die Grabplatten des Klosters Sonnenkamp (Rostock: [Univ.], 2011), 36-38; Wolfgang Eric Wagner, Die Grabplatten des Klosters "Zum Heiligen Kreuz" in Rostock (Rostock: Redieck \& Schade, 2007), 36-41. Similar elements can occasionally be found in the second half of the 15th century as well; however, at that time most of the grave slabs are no longer incised but in low relief. See Falko Bornschein, Grabplatten für die Geistlichkeit des Marienstiftes im Dom zu Erfurt aus der Zeit von 1470 bis 1550 (Erfurt: Verein für die Geschichte und Altertumskunde, 1997), 108-119.

7 Brieflade 4: Siegel und Münzen, T. 20, no. 25, T. 24, no. 13, 15-17, T. 31, no. 4-8, T. 36, no. 7-9. 


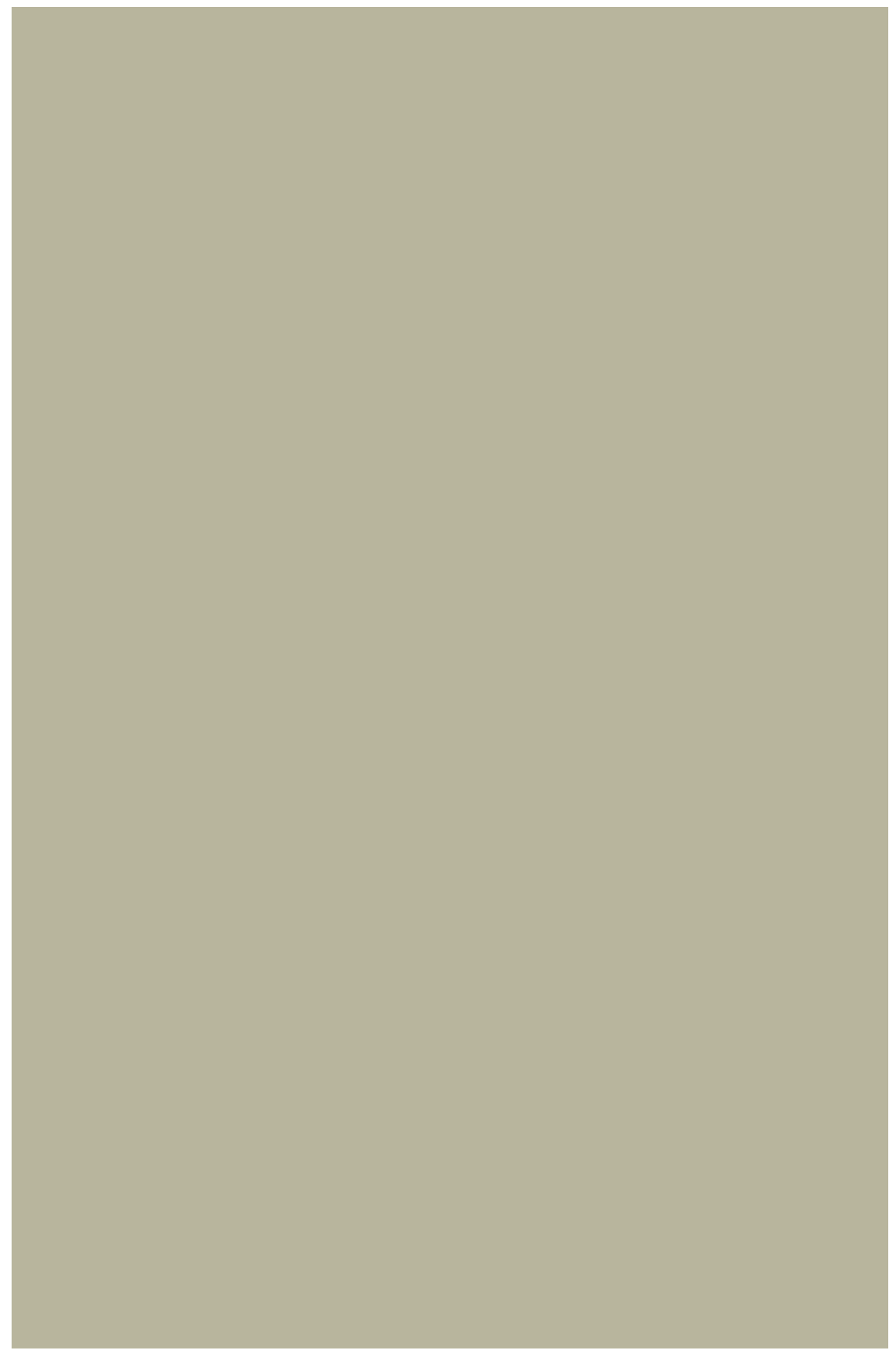

Fig. 2. Grave slab of the priest Borchardus Plotze, 1437. Stralsund, St Nicholas's Church. Photo by Anu Mänd. 
The inner row reads: [---]erat(?) o[mn]i te[m]pore d[---]s / cur ut saluetur homo xpm (= Christum) quisq[ue] precetur. Translation of the text on the right side: "For a man to be saved, everyone must pray to Christ."

Most Late Medieval grave slabs in Estonia have much shorter standard inscriptions, which fit into one row framing the slab and which indicate nothing more than the date of death, the name, title and/or position of the deceased and end with a traditional formula, such as "pray for his soul" or "may his soul rest in peace". The text on Stephanus's slab is obviously a more elaborate one, suitable for a man of his position.

It is clear that the stone carver who cut the letters into its surface, did not know Latin (indeed, he could well have been illiterate) and that the text was most probably composed by a cleric. The latter may also have given instructions for the general decoration of the slab. The cooperation between learned men and (illiterate) craftsmen in the production of the textual parts of art and artefacts is a field that has yet to be sufficiently studied. Local written sources provide little information about how the texts were executed in different visual media. For instance, in 1437 when a new bell was cast for St Olaf's Church in Tallinn, the sacristan (Ger. Küster) was paid for the placing the letters on the bell mould (and possibly for composing the text). ${ }^{8}$ It is probable that the few grammatical errors in the inscription of the grave slab (e.g. stephani instead of stephano) can also be explained by the craftsman's having no knowledge of Latin: even if the layout of the text was made by someone else, he could have "misread" some letters. For instance, in local metalwork, there are cases of the sequence of letters being reversed, letters being left out or replaced, or inscriptions being placed on the vessel upside down. The most eloquent examples are the Latin inscriptions on the silver-gilt chalice from St John's Church in Riga and on the bronze aquamanile from Adavere. ${ }^{9}$ Inscriptions in the vernacular, i.e. Middle Low German, were probably easier to execute, but mistakes were still likely to occur.

It is surprising that there is no date of death in the inscription; which usually follows the year. The assumption that the commissioning of a grave slab took so long that, by the time the inscription was prepared, the exact date was no longer known does not sound convincing. Another

8 Tallinn City Archives (Est. Tallinna Linnaarhiiv, abbr. TLA), coll. 230, inv. 1, no. Ad 14, fol. 6r: It. gegeuen dem koster de de bockstaue lede op de forme - $1 f$.

9 Anu Mänd, Kirikute hõbevara: altaririistad keskaegsel Liivimaal, Eesti kirikute sisustus 1 (Tallinn: Muinsuskaitseamet, 2008), 70-71, 124-125. 
possibility is that the date (i.e. the feast or saint's day) was placed at the beginning of the text, not after the year. Considering the size of the broken part, there would have been plenty of room for that. Although in most cases, the grave inscriptions begin with the year, there are some instances where the date precedes the year. ${ }^{10}$

The year of death is followed by praise to the deceased and only then by his name and occupation - vicar. The latter could refer to various ecclesiastical offices (from a deputy of the bishop to a chantry priest), depending on the institutional context. ${ }^{11}$

The text on the left side of the slab begins with the words cum stephani (sic!), which may indicate that someone else died and was buried together with Stephanus. However, one cannot be sure because the following three or four words are so damaged that they cannot be deciphered with certainty. If someone was indeed buried under the same grave slab, he could have been his parent, brother or a fellow cleric, which is perhaps the most plausible version in the context of the cathedral chapter. ${ }^{12}$ The inclusion of two rows in the design of the slab could also be an indication of the plan to provide enough space for epitaphs for two individuals. But it is also possible that cum stephani can be interpreted in a different way once the following words can be identified.

Thus far, no data has been found on Stephanus de Velde in documentary sources from medieval Livonia; i.e. before his grave slab was found, his existence was unknown. Hinricus (I) de Velde was the Bishop of Tartu in the 1370s (died in 1378), and a canon of the same name is recorded in the second half of the $14^{\text {th }}$ century ${ }^{13}$, but it is not known if Stephanus was related to them. The family name Velde (de Velde, van dem Velde) did not occur very frequently but was also not very rare: in

10 See e.g., Arthur Semrau, Die Grabdenkmäler der Marienkirche zu Thorn (Thorn: E. Lambeck, 1892), 23, no. 2, 24, no. 4 .

11 M.-L. Heckmann, "Vikar", Lexikon des Mittelalters, hrsg. v. Norbert Angermann et al., Bd. 8 (München: Deutscher Taschenbuch Verlag, 2003), 1662-1664.

12 E.g., in the Holy Cross convent in Rostock, two brothers, who were clerics, were buried under the same grave slab in 1394 and after 1420. Wagner, Die Grabplatten des Klosters "Zum Heiligen Kreuz", $52-53$. The sharing of a slab was more widely spread among the nuns (Ibid., 42-43, 68-69, 76-87, $104-$ 109), but they could also share a slab with their family members (Ibid., 102-103, 120-121, 140-141).

13 Leonid Arbusow, Livlands Geistlichkeit vom Ende des 12. bis ins 16. Jahrhundert, Dritter Nachtrag (Mitau, 1913), 53-54, 303, 312; Tõnis Lukas, Tartu toomhärrad 1124-1558 (Tartu: Tartu Ülikooli Kirjastus, 1998), 213. The grave slab of Bishop Hinricus was still extant prior to World War I, see Johann Christoph Brotze. Estonica, hrsg. v. Ants Hein, Ivar Leimus, Raimo Pullat, Ants Viires (Tallinn: Estopol, 2006), 260-261. 
the $15^{\text {th }}$ century, the name Velde turns up, for instance, in sources from Lübeck, Tallinn and Riga. ${ }^{14}$

According to the expert Helle Perens, Stephanus's grave slab is made of Lasnamäe limestone. ${ }^{15}$ The city of Tallinn was an important centre for the production and export of limestone products, including floor tiles, door-side stones (Ger. Beischlagsteine), tombstones, and so forth. The ready-made or semi-manufactured products were exported to southern Livonian cities, such as Riga and Tartu, where limestone was not available, as well as to northern Germany (e.g. Lübeck, Danzig and Stralsund) and elsewhere in the Baltic Sea region. ${ }^{16}$ It cannot be ascertained if Stephanus's slab was brought to Tartu as a simple slab and carved by a local master or commissioned from a Tallinn stone carver.

Prior to the two World Wars, about a dozen medieval grave slabs of ecclesiastics from the Tartu Cathedral still existed, some of them decorated with full figures, others with suitable symbols, such as chalices or family coats of arms ${ }^{17}$ Only one of them, decorated with only an inscription and empty circles in the corners, survived the destructions of the wars and is currently exhibited at the entrance to the University of Tartu's History Museum. ${ }^{18}$ Therefore, the slab found in 2008 is a valuable addition to our knowledge about how the grave slabs were designed and how the memory of the clerics was perpetuated on their sepulchral monuments.

\section{GEORGIUS BARDIN}

The grave slab of Georgius Bardin (Fig. 3) in the Tallinn Cathedral is the only one in Estonia depicting a full figure of a canon in low relief. The slab, made of Lasnamäe limestone, is located in the floor of the sacris-

14 Gunnar Meyer, „Besitzende Bürger” und „elende Sieche”: Lübecks Gesellschaft im Spiegel ihrer Testamente 1400-1449 (Lübeck: Schmidt-Römhild, 2010), 499 (four Veldes); Liv-, Est- und Kurländisches Urkundenbuch (hereafter LUB), vol. 12, no. 354; TLA, coll. 191, inv. 2, no. 1, fol. 6r (Diderick van dem Velde entered the Great Guild in 1405); Das Revaler Bürgerbuch 1409-1624, hrsg. v. Otto Greiffenhagen (Tallinn, 1932), 15 (Tzories van dem Velde became burgher in 1436); Die Erbebücher der Stadt Riga 1384-1579, bearb. v. J. G. L. Napiersky (Riga: Kymmel, 1888), 143, no. 25, 154, no. 81.

15 E-mail from Helle Perens, 7 January 2014.

16 See Paul Johansen, Heinz von zur Mühlen, Deutsch und Undeutsch im mittelalterlichen und frühneuzeitlichen Reval (Köln, Wien: Böhlau, 1973), 176-177; Wilhelm Stieda, "Kabelgarn und Steine, zwei Revaler Ausfuhrartikel”, Beiträge zur Kunde Ehst-, Liv- und Kurlands, Bd. 7 (1912), 184-187.

17 See Johann Christoph Brotze. Estonica, 256-279, 282-283.

18 It belongs to the vicar Ottemar Dole, who died in 1454. 


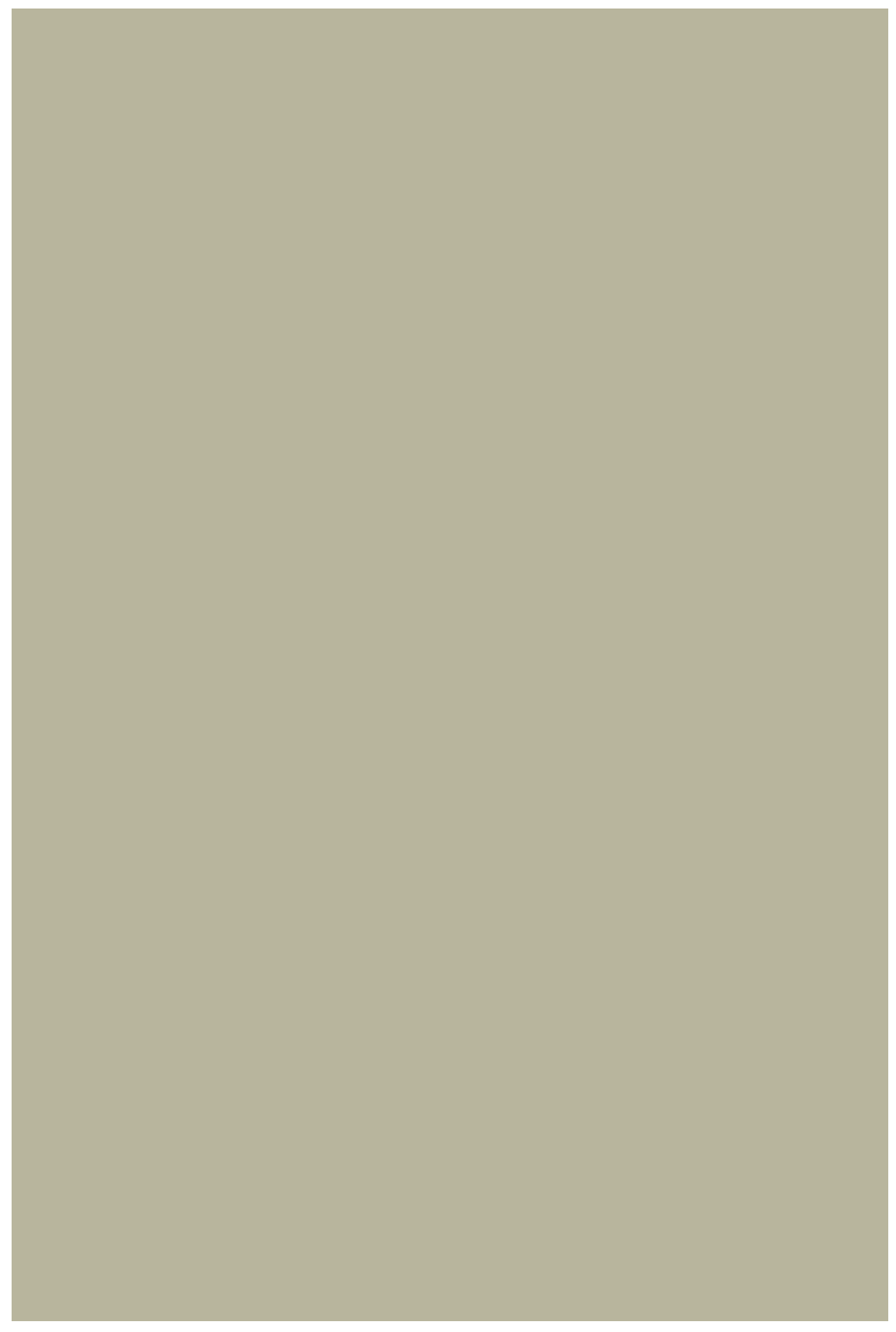

Fig. 3. Grave slab of Georgius Bardin, 1525. Sacristy of the Tallinn Cathedral. Photo by Stanislav Stepashko. 
ty, near the northern wall. Its right side is partly covered by a radiator's support brackets.

The object has been briefly mentioned in studies by Mari Loit and Sulev Mäeväli; however, both authors provide an incomplete and incorrect inscription. ${ }^{19}$ The uppermost part of the slab, including the beginning of the text, has not been preserved. The inscription in Gothic minuscule reads as follows: [---] / xxv in die inve[n]tionis s[an]cte crucis obiit / v[e]n[er] abil[is] d[omi]n[u]s inge[nuus] (or: inge[nius]) / georgius bardi[n] reuali[ens]i[s] ozili[ens]i[s] eccl[es]iaru[m] can[oni]c[us]. The corners are decorated with the symbols of the Evangelists surrounded by the circles. At the lower end, one can see the winged ox of St Luke and winged lion of St Mark. At the upper end, only the lower halves of the circles have been preserved; however, the feet and claws of St John's eagle in the left corner and the feet of St Matthew in the right can still be recognised. The slab measures c. $243 \times 150 \mathrm{~cm}$, but originally it was about $25 \mathrm{~cm}$ longer.

Bardin's rank as canon is clearly visible from the slab: the figure is wearing typical canon's headgear and liturgical vestments. He is holding the Chalice - the most frequent attribute of a cleric - in his left hand and he is making a sign of blessing with his right hand. At his feet, there is a shield with the family coat of arms - three six-pointed stars. Instead of a canopy, there is a round-arched thistle ornament above him, indicating the growing influence of the Renaissance. The general design of the slab and the shape of the letters, however, follow Gothic traditions.

Georgius (Jurgen) Bardin (also Bardien, Bardyn) was a canon in the Saare-Lääne (Lat. Osilia) diocese from 1503, and from at least 1519, also in the Tallinn (Reval) diocese. He is last mentioned in a document from 20 July $1524 .{ }^{20}$ Thus far, his date of death was unknown, but the inscription on his grave slab tells us that he died on the day of the Finding of the Holy Cross (i.e. 3 May) in 1525.

Although in the last five or six years of his life, he simultaneously served as a canon in two dioceses, he apparently resided in Tallinn and therefore was buried there. In addition to the Cathedral on Toompea Hill, he was also connected to a parish church in the Lower Town: in February 1522, he founded a perpetual chantry in honour of the Annunciation of the Virgin in the Chapel of the Virgin Mary at St Olaf's Church (the

19 Loit, "Keskaegsest surmakultuurist ja hauatähistest", 73-74, 79, ill. 4; Sulev Mäeväli, Matustest ja hauatähistest Tallinna toomkirikus (Tallinn: Morgan Stuudio, 2004), 9-10.

20 Arbusow, Livlands Geistlichkeit, Dritter Nachtrag, 11-12. 
mass had to be sung each Wednesday). ${ }^{21}$ The newly built chapel was very prestigious and therefore attracted several wealthy donors who wished to establish their commemorations there. ${ }^{22}$

In addition to Bardin's slab, there are four other medieval grave slabs and an altar table (mensa) in the sacristy floor of the Cathedral. All of these were discovered in 1983 when the wooden floor was removed in order to install a new heating system. ${ }^{23}$ At least two of the other grave slabs also belong to canons. The largest of these, which is located in front of the current altar and partly covered by it, is so worn that only part of the inscription is legible. In the middle, there is a figure of a canon - the typical headgear can still be recognized - but this is also barely visible. The slab adjacent to it, near the eastern side of the southern wall, is in much better condition - only its lower (i.e. the eastern) end is missing. The slab is decorated with the coat of arms of the Rotert family and the inscription reads as follows: Anno d[omi]ni m cccc / lxxxvi fe[r]ia q[ua]rta post visitac[i]o[n] is marie obiit vene[r]abil[is] vir / [---] / <r>otert h[uius] eccl[es]ie canonic[us] cui[us] a[n]i[m] in perpetua pace req[ui]escat. Thus, the canon Rotert, whose first name is unknown since his name cannot be found in any written sources, died on 5 July $1486 .{ }^{24}$

The grave slabs in the sacristy are not (at least not yet) included on the list of protected cultural monuments as are the ones in the nave and aisles of the Cathedral. It is not entirely clear if the slabs were originally placed in the floor of the sacristy or if they were moved there after the Middle Ages to make room for new funerals in the main body of the church. On the one hand, as can be seen from the descriptions above, the ends of some slabs have been cut. It has also been pointed out that there are some discrepancies between the grave slabs and the

21 TLA, coll. 230, inv. 1-I, no. 963 (15 Feb. 1522). In the charter, he is referred to as Meister Jurgen Bardin, tho Osell vnnd vnser kerckenn to Rewell domherre. See also Anu Mänd, "Church Art, Commemoration of the Dead and the Saints' Cult: Constructing Individual and Corporate memoria in Late Medieval Tallinn", Acta Historica Tallinnensia, 16 (2011), 17, note 74.

22 Mänd, "Church art, commemoration of the dead and the saints" cult", 16-17.

23 Loit, "Keskaegsest surmakultuurist ja hauatähistest", 73. Loit mentions six grave slabs but one of these is actually a mensa of a former side altar, decorated with five small crosses, four in the corners and one in the middle.

24 Johannes Rotert, Bishop of Tallinn 1531-1536, originated from the same family, but nothing is known of the canon who died in 1486 (unless he is Everhard Rotert, provost in the Saare-Lääne diocese in 1473). For Everhard and Johannes, see Arbusow, Livlands Geistlichkeit, Dritter Nachtrag, 177-178. For the coat of arms of Bishop Rotert, see Brieflade 4: Siegel und Münzen, 122, T. 32, no. 21. For the family, see Karlheinz Volkart. "Die Rotert - hansische Kaufleute in Reval", Genealogie: Deutsche Zeitschrift für Familienkunde, 21. Jg., H. 12 (1972), 364-370. 
basement. ${ }^{25}$ On the other hand, the grave slabs were placed in the floor with the correct east-west orientation, i.e. the "feet" to the East and the "head" to the West. In 1742 when J. M. Litschio made a floor plan of the Cathedral and listed the grave slabs, he did not name or mark those in the sacristy. However, he mentioned the fact that five graves are located there ${ }^{26}$, which corresponds to the number of the extant slabs. It is probable that the sacristy was used as a burial place in the Middle Ages, in the manner of a chapel. It is known that in North-German churches, the sacristies were occasionally used as chapels and that altars sometimes stood there. ${ }^{27}$ Thus, Rotert, Bardin and some other members of the cathedral chapter could have chosen to be buried in the sacristy. But, it is also possible that, when making note of five graves, Litschio had the same extant slabs in mind and that they had been brought there from the nave or aisles prior to 1742 . The question remains, to be solved by future studies of the sacristy floor.

\section{A MYSTERIOUS BISHOP}

The third case turned out to be the most challenging one, raising more questions than providing answers. In the floor of the northern aisle of the Tallinn Cathedral, at the easternmost pillar, there is a Late Medieval grave slab of a bishop (Fig. 4). Only a half of it is visible; the other half is covered by a massive set of late $17^{\text {th }}$-century pews which cannot be removed. The right side, which is visible, is extremely worn. One can see that there was an inscription but none of it can be identified, even though a word right next to the pews has suffered somewhat less damage. ${ }^{28}$ The upper end of the slab, the upper right corner and a small part of the lower right corner are missing. The corners have been traditionally decorated with the symbols of the Evangelists, of which a partly surviving ox of St Luke can be seen in the lower right corner.

25 Loit, "Keskaegsest surmakultuurist ja hauatähistest", 74-75.

26 Henry von Baensch, Geschichte der Familie von Wrangel vom Jahre zwölfhundertfünfzig bis auf die Gegenwart (Berlin, Dresden: W. Baensch, 1887), T. 1, 57-60 (list of grave slabs), floor plan of 1742 next to p. 88; Mäeväli, Matustest ja hauatähistest Tallinna toomkirikus, 43 (remark: "Die Geräthkammer mit ihren fünf Gräbern").

27 Antje Grewolls, Die Kapellen der norddeutschen Kirchen im Mittelalter (Kiel: Ludwig, 1999), $160-162$.

28 The word could be ecclie (i.e. ecclesiae). 


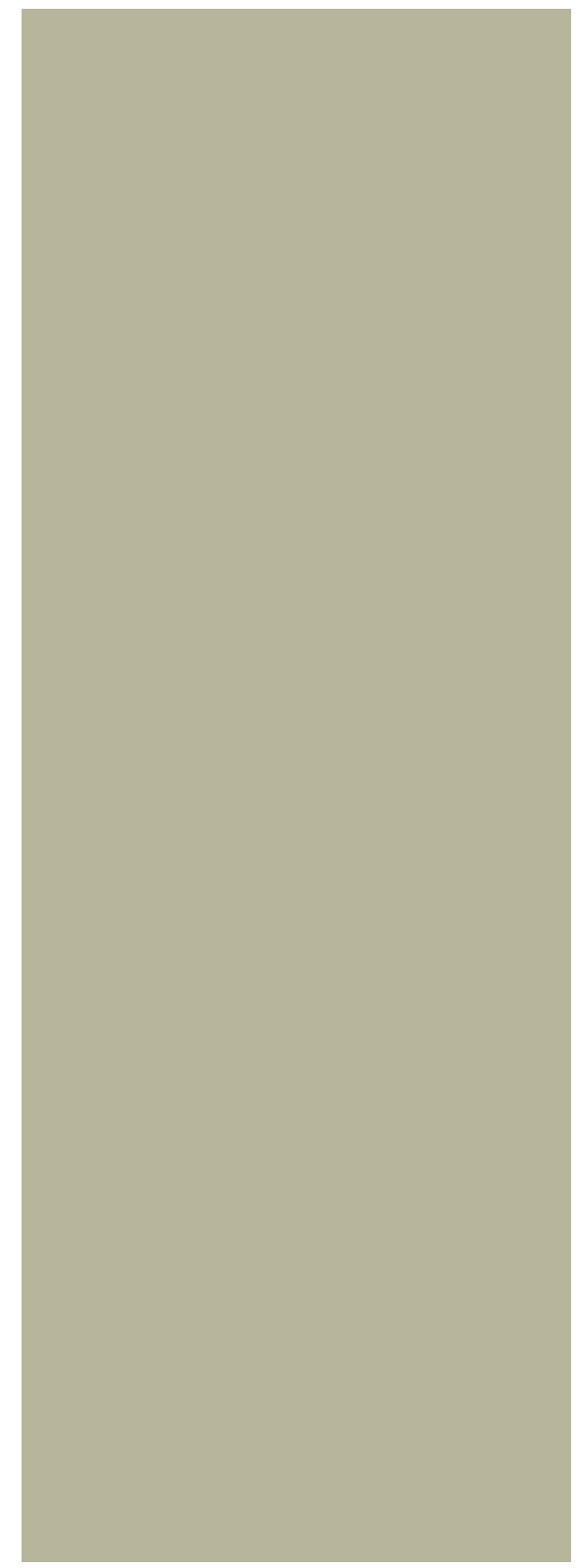

Fig. 4. Grave slab of a bishop, first third of the 16th c. North aisle of the Tallinn Cathedral. Photo by Stanislav Stepashko.

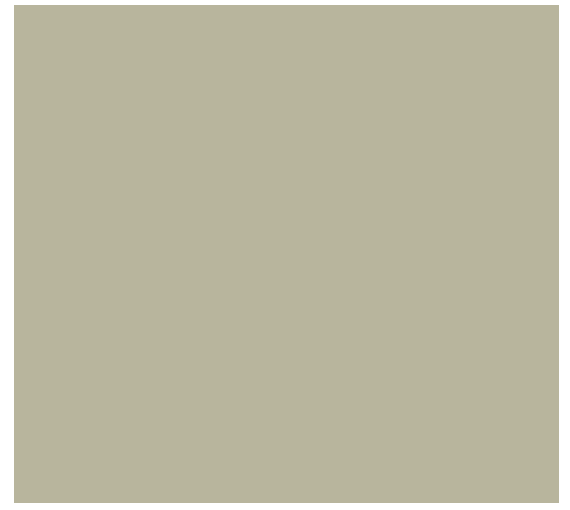

Fig. 5. Lower left corner of the bishop's grave slab with the symbol of St Mark. Photo by Stanislav Stepashko.

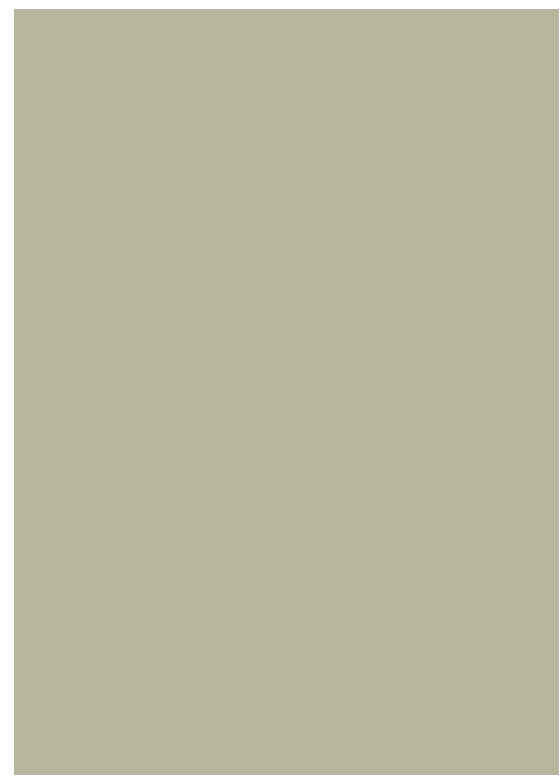

Fig. 6. Fragment of the coat of arms on the bishop's grave slab. Photo by Stanislav Stepashko. 
The central figure in low-relief is somewhat less worn because it is right next to the pews and therefore has been stepped on less. The figure can be identified as that of a bishop: the visible parts reveal a fragment of the mitre and liturgical vestments, including the maniple hanging from the left arm. On the lower part of the slab, there seems to be a fragment of a pastoral staff, which continues under the pews. An incised number 49 is located to the right of the bishop's head: this originates from the $17^{\text {th }}$ century when the slabs were marked with numbers. ${ }^{29}$ At the bishop's feet, one can see the fragment of a coat of arms and a tablet with a three-line inscription. Although some single letters can be identified, the text as a whole is illegible.

Just like the two grave slabs discussed above, this one is also made of Lasnamäe limestone. Its dimensions are approximately $270 \times 210 \mathrm{~cm}$. Scholars agree that the slab is in its original position and there is a tomb under it. Due to its late Gothic design, the slab has been dated to the late $15^{\text {th }}$ or early $16^{\text {th }}$ century. ${ }^{30}$ Based on this approximate dating, it has been assumed that the bishop in question is either Simon von der Borch (in office 1477-1492) or Nicolaus Rodendorp (1493-1509). ${ }^{31}$

Although the heavy set of pews cannot be moved, in January 2014, it was possible to temporarily remove some planks from their wooden floor (the central support beam and iron pipes under the pews remained in place). As a result, it was possible to study and photograph some parts of the left side of the slab, particularly the lower left corner (Fig. 5), which, as was to be expected, is in a much better shape than the visible half. One could see a quatrefoil with a well-preserved symbol of St Mark: a winged lion holding a scroll. More importantly, some parts of the Latin inscription in Gothic minuscule became visible: obit a[n]no / $m v^{c}$, i.e. died in the year 1500. Unfortunately, the text breaks off in the middle of the date; the rest of the left row is blank as if the inscription had been removed or covered up on purpose (perhaps by a later owner of the slab?). Although the name of the deceased is not inscribed in the lower left corner, at least it is now clear that we are dealing with a $16^{\text {th }}$-century bishop. On the uncovered part of the slab, one can also no-

29 Loit, "Keskaegsest surmakultuurist ja hauatähistest", 72.

30 The slab is in the National Registry of Cultural Monuments (reg. no. 1340): http://register.muinas.ee/?menuID = monument\&action $=$ view\&id $=1340$.

31 Raul Vaiksoo, “Tallinna toomkirik. Hauaplaadid” (Tallinn, 2003), manuscript in the archives of the Tallinn Culture and Heritage Department (Est. Tallinna Kultuuriväärtuste Amet), 5, no. 11; Mäeväli, Matustest ja hauatähistest Tallinna toomkirikus, 10. 
tice a tablet with a three-line inscription, similar to the one on the right side. I have not been able to decipher the entire text, but here are the preliminary results: pl[ur]es vi/ta lab[---] / et [---]ola. In any case, the text on the two tablets seems to be either a prayer or a verse and does not include the name of the bishop. Finally, a small fragment of the coat of arms became visible, revealing that the shape of the shield is similar to the one on Bardin's grave slab. This type of shield was used in Livonian seals from about 1505 to about $1535 .{ }^{32}$ Considering all of the above, it can be surmised that the slab most likely originates from the first third of the $16^{\text {th }}$ century.

The only clue to the bishop's identity is his coat of arms, which depicts an animal rampant, turned to face the viewer's right (Fig. 6). However, here one encounters some difficulties. Firstly, the hind part of the animal cannot be seen and its species is not clear: it seems to have paws, not hooves, and its nose resembles that of a rodent or a hare. The small pricked-up ears could belong to a squirrel (or perhaps a hare). With some hesitation, one could also consider a dog, although the mouth seems too small. But what is even more puzzling is that none of the Tallinn bishops in the $16^{\text {th }}$ century (or earlier) had this kind of emblem on their coat of arms. ${ }^{33}$ It also does not belong to any bishop or archbishop in other Livonian dioceses. It cannot be ruled out that a foreign bishop might have died and been buried in Tallinn, but there is no documentary evidence for this.

The only $16^{\text {th }}$-century bishop of Tallinn, whose coat of arms is unknown, is Christianus Czernekow, who was in office for a very short time from 1513 to 1514 . He was the city scribe of Tallinn in from 1487 to 1507 and 1512 to 1513, and also a canon from at least 1495. In late September 1513 he was still fulfilling his duties as scribe, but in October he was already described as a bishop. He was still alive on 6 July 1514, but must have died soon after that. ${ }^{34}$ There are no surviving sealed letters or charters by Bishop Czernekow in the Tallinn City Archives, and it is not known if he even managed to acquire a seal prior to his early death. He came from a burgher's family in Danzig and it is likely that, while

\footnotetext{
32 Brieflade 4: Siegel und Münzen, T. 25, no. 23, T. 32, no. 13, 21, T. 47, no. 15, 19, T. 59, no. 22.

33 See Brieflade 4: Siegel und Münzen, 119-123, T. 32-33.

34 On him, see Arbusow, Livlands Geistlichkeit, Dritter Nachtrag, 117-118; Torsten Derrik, Das Bruderbuch der Revaler Tafelgilde (1364-1549), Mikrofiche-Ausgabe (Marburg: Tectum, 2000), 330 332 (in the Internet version of the book, 245-246).
} 
serving as the scribe, his seal was a simple house mark. In 1499, years before being elected bishop, he drew up a will: there is a paper seal on its verso, depicting a house mark, but it does not belong to Czernekow, because it includes the initials JP. ${ }^{35}$ For these reasons, it cannot be ascertained if the coat of arms on the grave slab belongs to Czernekow or not.

There is, however, another source to be considered. In his "Liber Collectaneus" (1627), the Swedish pastor and antiquarian Martin Aschaneus lists eleven medieval grave slabs of ecclesiastics in the Tallinn Cathedral, eight of which belonged to bishops. ${ }^{36}$ There are several mistakes in his transcriptions of Gothic texts, particularly in the names and dates (e.g. according to him, Simon von der Borch died in 1414, whereas he really died in 1492). However, scholars have generally believed that his description of the slab of Bishop "Christian Verkoln" can be attributed to Czernekow and that he simply misread the name. ${ }^{37}$ Be that as it may, but the extant slab cannot be linked to Aschaneus's description. In his transcription, there is no 'obit anno' and the date of death is written in full words, not in Roman numerals: $A^{\circ}$ Dni millessimo quingentesimo Decimo quinto, 16 die Julii, ob. Rdus Pater et Dns. Dn. Christian Verkoln, huius Eccl. Episcps. ${ }^{38}$ Thus, it is obvious that, even if the slab which Aschaneus described belonged to Czernekow, our slab is not identical to it. The only inscription cited by Aschaneus that could theoretically belong to the extant slab, is from the tombstone of Nicolaus Rodendorp: it includes the words qui ob. $A^{o}$ Dni M. VC. IX. ${ }^{39}$ If we consider that Aschaneus was more creative than meticulous, it is possible that we are dealing with the same text. However, as indicated above, the animal on the coat of arms does not belong to Bishop Rodendorp, who had half of a lily in the dexter part of his shield and two rafters in the sinister part. ${ }^{40}$

Aschaneus was the last one known to have described the grave slabs in the Cathedral. The fire of 1684 destroyed most of the furnishings

35 TLA, coll. 230, inv. 1, no. BN 1, Czernekow (16 July 1499); published in LUB 2/1, no. 845. The loose seal does not belong to any of the executors of the will either; moreover, its shape is characteristic to the mid-16th century. Therefore it is likely that it has no connection to the document $(A . M$.). 36 The inscriptions are published by Carl Schirren, Verzeichniss livländischer Geschichts-Quellen in schwedischen Archiven und Bibliotheken, 1. Heft (Dorpat, 1861), 211-212.

37 Arbusow, Livlands Geistlichkeit, Dritter Nachtrag, 118; Loit, "Keskaegsest surmakultuurist ja hauatähistest", 77 .

38 Schirren, Verzeichniss livländischer Geschichts-Quellen, 212, no. 9.

39 Ibid., 212, no. 8.

40 Brieflade 4: Siegel und Münzen, 119, T. 32, no. 12-13. 
and also several tombs in the main body of the church. ${ }^{41}$ When Litschio composed his floor plan in 1742, the slabs were named after their contemporary owners: no. 49 is listed as belonging to the Rosenfeld and Köhler families. ${ }^{42}$ In 1800 and 1802, Pastor Eduard Philipp Körber, who made drawings of several historical monuments in Estonia, searched in particular for the grave slabs of bishops in the Tallinn Cathedral but did not find any. ${ }^{43}$ It is very likely that he simply did not notice the worn slab, only half of which is visible.

Thus we must face the fact that no other grave slabs of bishops have survived in the Tallinn Cathedral, except for the one that cannot be identified. The only other extant slab of a Tallinn bishop is located in the chancel of the Church of the Holy Trinity in Rakvere: it was found in the early $19^{\text {th }}$ century in the ruins of the Franciscan friary in the same town and belongs to Bishop Arnoldus Anebat (1536-1551). ${ }^{44}$ No complete grave slabs of bishops survive from the other two cathedrals in the Estonian territory either: all that is left are some small fragments and drawings from the late $18^{\text {th }}$ and the early $19^{\text {th }}$ century. ${ }^{45}$

\section{CONCLUDING REMARKS:}

\section{THE VISUAL COMMEMORATION OF CLERICS}

Considering the fact that none of the three slabs are fully preserved - each has suffered greater or lesser losses - it may sound ironic that, together with the slab of Anebat from 1551, these are the best surviving examples of figural tomb monuments of ecclesiastics in Estonia. The few others that have survived are in a much worse condition and mostly unidentifiable.

Based on the imagery, the grave slabs of ecclesiastics can be divided into four main groups: decorated with a full figure (incised or in low relief), with the Chalice (with or without the Host) as the symbol of the

41 Gotthard von Hansen, Die Kirchen und ehemaligen Klöster Revals. Dritte vermehrte Auflage (Reval: Kluge, 1885), 59-60; R[udolf] Winkler, Der Brand des Doms zu Reval im Jahre 1684 (Reval: Mickwitz, 1906), 4-7, 9, 11.

42 Baensch, Geschichte der Familie von Wrangel, 58, no. 49; Mäeväli, Matustest ja hauatähistest Tallinna toomkirikus, 43.

43 Johann Christoph Brotze. Estonica, 171.

44 The slab is in the National Registry of Cultural Monuments (reg. no. 16945): http://register.muinas.ee/?menuID=monument\&action=view\&id=16945. See also Johann Christoph Brotze. Estonica, 171-173; Brieflade 4: Siegel und Münzen, T. 33.

45 See, e.g., Johann Christoph Brotze. Estonica, 12-13, 171-173, 260-261, 283. 
Eucharist, with a coat of arms, and with nothing else but an inscription. It is clear that the slabs with representations of full figures were the most elaborate and attractive ones, required the carver to have greater skills, and were more expensive than the simpler ones. We are thus dealing with prestigious objects, which were meant not only to mark the tomb but also to visually commemorate the deceased, to invite the viewers to contemplate death, salvation and resurrection, and to evoke intercessory prayers.

Another important function of these monuments was to be a witness to status. ${ }^{46}$ The standing of the deceased was expressed in several ways. First, all three men are visually recognizable as clerics based on their liturgical garment and headgear. They are also carrying attributes typical of a cleric: a book in the case of Stephanus de Velde and the Chalice in the case of Georgius Bardin. However, their attire does not merely reveal their clerical estate but can be "read" more specifically: due to the characteristic details, even an illiterate viewer could easily identify a priest, a canon and a bishop. For the educated viewers, the status of the deceased was also underlined in the inscriptions (vicarius and canonicus).

Even though in the later Middle Ages, the figures on sepulchral monuments were generally depicted with growing individuality, this is barely visible in our examples. The incised slab of Stephanus is particularly schematic, representing an idealized and ageless figure. The face of Georgius Bardin, executed about ninety or a hundred years later, reflects certain individual features (crow's feet and a double chin), but here too, one cannot speak of an 'authentic portrait' but of a visual construction of a 'typical' elderly and learned man. The characters on the grave slabs generally represented idealised figures, often in the prime of life, as they would appear on Judgement Day. ${ }^{47}$

It has sometimes been argued that, unlike the laity's monuments, those of the clergy were less commemorations of the individual than of the clerical estate as a whole. ${ }^{48}$ On the other hand, as is also visible from our slabs, the commissioners of the slabs paid great attention to the visual and textual expression of the identity. The memory of the deceased was perpetuated through the proper attire and symbols, but even more so,

46 Nigel Saul, English Church Monuments in the Middle Ages: History and Representation (Oxford University Press, 2009), 205.

47 Saul, English Church Monuments in the Middle Ages, 144-145.

48 Ibid., 205-206. 
through the family coats of arms and the names and occupations stated in the inscriptions. And last but not least, the grave slabs with their carefully constructed imagery and their spatial and liturgical context formed only a part of the complex system of commemoration, which could also include the Word, music, illumination and rituals.

Anu Mänd: Vicarius, Canonicus et Episcopus: Three Late Medieval Grave Slabs From Tartu and Tallinn

Keywords: Medieval Gravestones in Estonia, Epigraphy, Ecclesiastical Dignitaries, Culture of Commemoration, Iconography of Sepulchral Monuments

SUMMARY:

The article discusses three late medieval grave slabs in Estonia, which are decorated with full figures and represent ecclesiastics of different ranks. By examining their visual appearance, including the inscriptions and coats of arms, some of the general trends in the production and decoration of local tombstones can be outlined and a contribution made to the discussion of the role of such monuments in the late medieval culture of commemoration.

One of the slabs, actually a fragment, came to light during the archaeological excavations of the Tartu Cathedral in 2008. Its inscription added a completely new name to the list of clerics known from medieval Tartu. The monument belonged to the vicar Stephanus de Velde, who died in 1428 or 1438 . The others two grave slabs are located in the Cathedral of Tallinn. One of them, belonging to an unidentified bishop, can be dated to the first third of the $16^{\text {th }}$ century. The other marks the grave of Georgius (Jurgen) Bardin, a canon in the Tallinn and SaareLääne (Ösel-Wiek) dioceses, who died in May 1525.

An important function of these monuments was to be a witness to status. The identity of the deceased was perpetuated through the proper attire and symbols, but also through the family coat of arms and the name and occupation stated in the inscription. The large and elaborately 
decorated grave slabs were prestigious objects, which were meant not only to mark the tomb but also to visually commemorate the deceased, to invite the viewers to contemplate on death, salvation and resurrection, and to evoke intercessory prayers.

CV:

Anu Mänd is senior research fellow at the Institute of History of Tallinn University. She has published several monographs, including Urban Carnival: Festive Culture in the Hanseatic Cities of the Eastern Baltic, 13501550 (Brepols, 2005), based on her Ph.D. dissertation. Her main research interests are in the social and cultural history of medieval Livonia. She is currently working on altars and altarpieces, guilds and confraternities, gender and memoria. 